\title{
Resenha de "Pelas Lentes do Cinema: Bioética e Ética em Pesquisa"
}

\author{
Review of "Through the Lens of Cinema: Bioethics \\ and Research Ethics"
}

Maria Laura Sandeville ${ }^{I}$

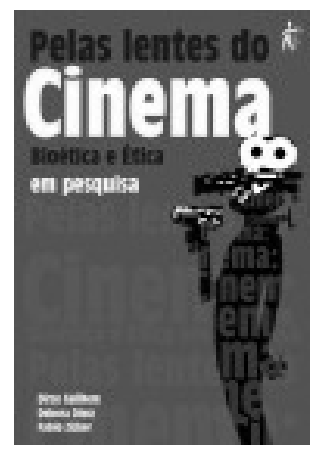

Resenha da obra de: Guilhem D, Diniz D, Zicka F (Eds.): Pelas Lentes do Cinema: Bioética e Ética em Pesquisa. [Brasília]: Ed. UnB; 2007.

Os editores do livro Pelas lentes do cinema: bioética e ética em pesquisa reuniram cineastas, jornalistas, médicos, enfermeiros, membros de comissões de ética, bioética ou ética em pesquisa, escolheram um título intrigante e uma proposta atual, sobremaneira em um país que viveu a polêmica votação - pelo Supremo Tribunal Federal - da legalização da pesquisa com células-tronco e viverá a votação da legalização do aborto de fetos anencéfalos, matéria do documentário Uma história Severina, discutido neste livro.

Inicialmente, especialistas em linguagem visual introduzem o cinema, a imagem e a narrativa, constituindo a primeira parte do livro. Leitura densa para não especialistas e, por vezes, repetitiva em conceitos, datas, "apresentações" e "introduções". Mas o projeto do livro é soberano.

Os autores propõem o cinema como instrumento da ética. Sugerem a apresentação de filmes em salas de aula com o intuito de aproveitar a sensibilidade e a capacidade argumentativa suscitadas por estes, instigando a discussão. A cada filme proposto, os autores fornecem resenha, tempo de filme, tempo de aula e um roteiro a seguir. Os temas abordados são: ética, bioética e pesquisas clínica, genética e comportamental. Enfatizam que a ética nas ciências humanas seja abordada em suas particularidades, pois transcende os fundamentos biomédicos que norteiam as pesquisas no Brasil. A repercussão de danos psicossociais causados por experimentos que exponham as pessoas à mídia pode ser desastrosa.

Em excelente exemplo, a antropóloga Débora Diniz relata os cuidados e questionamentos éticos que acompanharam o documentário Uma história Severina, dirigido por ela e por Eliane Brum. Severina era uma agricultora nordestina, analfabeta, que teve a vida alterada 
pelos ministros do Supremo Tribunal Federal quando estes suspenderam a autorização para o aborto do feto anencéfalo. Ela, que estava internada, recebeu alta hospitalar e teve a gravidez acompanhada em um estudo de caso até o parto induzido, dando à luz um natimorto. O Comitê de Ética, para a aprovação do projeto, considerou o cenário político e religioso e optou por submeter o documentário a um comitê colegiado, dado o importante impacto psicossocial do tema. O transtorno psicológico poderia ser subestimado pelos pesquisadores por se tratar de uma condição de extrema vulnerabilidade e poder perdurar além do término do estudo. Com propriedade e autocrítica, a autora questiona ainda se caberia algum ressarcimento à Severina em caso de sucesso ou premiação do filme. Felizmente, a remuneração em pesquisa é proibida no Brasil. Mas seria ético Severina não receber nenhuma participação em caso de retorno financeiro do documentário? Certamente questões polêmicas, mas que precisam ser debatidas, à semelhança do "benefício compartilhado" da pesquisa biomédica, que garante acesso ao medicamento estudado às pessoas que participaram da pesquisa.

Em síntese, o livro promove o diálogo sobre ética entre pesquisadores e sociedade, por meio do cinema. Esta obra é referência para aqueles que pretendem usar filmes como ferramenta de ensino.

\section{ENDEREÇO PARA CORRESPONDÊNCIA}

Instituto Israelita de Ensino e Pesquisa Albert Einstein.

R. Jesuino, 134, apto. 152

Itaim Bibi - São Paulo

CEP 05652-900 - SP

E-mail: sandeville@uol.com.br 